\title{
Production and Characterization of Ethanol Biogel, An Alternative Energy Source for Cooking
}

\author{
*Itoandon, Emoleila $E^{\mathrm{a}^{* b} \mathrm{~b}}$ Bankole, Samuel. A Ezeanyanso, C. S $\mathrm{S}^{\mathrm{c}}$ Nwachukwu, \\ Viola ${ }^{\mathrm{d}}$ Lasore, Olawale. $\mathrm{O}^{\mathrm{b}}$ \\ ${ }^{a}$ Department of Microbiology, Faculty of Sciences, Olabisi Onabanjo University, Ago Iwoye, Ogun state, \\ Nigeria \\ ${ }^{b}$ Enzyme Technology Division, Biotechnology Department, Federal Institute of Industrial Research, Lagos state, \\ Nigeria \\ ${ }^{c}$ Polymer and Textile Division, Federal Institute of Industrial research, Lagos state, Nigeria \\ ${ }^{d}$ Nutrition and Toxicology Division, Federal Institute of Industrial Research, Lagos state, Nigeria
}

\begin{abstract}
A research innovation on product development through principle of applied biotechnology was demonstrated for production of ethanol bio gel, an alternative cooking energy source. Bio ethanol was produced using pretreated sawdust as substrate by solid state fermentation technique using Aspergillus niger. The bio ethanol was further used in a combination with water and a nitrosol compound in a ratio (70:10:20) for production of ethanol biogel. Preliminary analysis showed that the ethanol biogel had the following properties; viscosity at $40 \mathrm{oC}$ and $80 \mathrm{oC}$ recorded (421.20cst and 210.87 cst respectively), flashpoint (26oC), density at $25 \mathrm{oC}$ $(0.908 \mathrm{~kg} / \mathrm{m} 3)$, total acid number $(0.12 \mathrm{mg} \mathrm{KOH} / \mathrm{g})$, pour point (-13\% still flowing) with $\mathrm{pH} 6.16$ having no base settlement and no water content. The flame produced was thinner compared to kerosene and wood flames. It also had a blueish colour full of motion, also odourless with complete combustion.
\end{abstract}

Keywords: Sawdust, Aspergillus niger, bioethanol, water, nitrosol, ethanol biogel, cooking

\section{Introduction}

Fuelwood, roots, agricultural residues and animal dung are known to produce high emissions of carbon monoxide, hydrocarbons and particulate matter that are particularly harmful to man and environment when used as energy source for cooking. The effects of exposure to indoor air pollution depend on: 1) the source of pollution, 2) how pollution is dispersed and 3) how much of their time household members spend indoors. The type of energy used and individuals' participation in food preparation have consistently been the most important indicators towards research and development into better form of cooking energy source. The use of traditional biomass as an energy source for cooking has generally taken much interest in this present day. However, reliance on biomass as the predominant source of energy for cooking is predicted to grow in the coming decades (Sander et al. 2011). These trends are due to rapid population growth which has outpaced efforts to scale up access to modern energy services. More than $95 \%$ of people in countries such as Burundi, Central African Republic, Chad, Liberia, Rwanda, the Gambia, Sierra Leone and Nigeria lack access to modern energy, with the rural population relying almost exclusively on wood-based biomass energy for cooking. Wood-based biomass as the main source of energy is reported at 96\% in Ethiopia, 90\% in Tanzania, 76\% in Kenya, and 67\% in Nigeria (IEA 2014). Use of cheap alternative sources of energy mainly for cooking is now an important issue to consider from several perspectives. Renewable energy from identified crops and lignocellulosic residues, agricultural and wood based, are undergoing worldwide economic analysis for efficient commercialization. The bioethanol production through microbial fermentation provides an economically competitive source of energy (Mcaloon et al. 2000; Yasuyuki et al. 2011). There are a variety of biotechnological processes and microbial mechanisms for biological fuel (ethanol) production from lignocellulosic and cellulosic materials. Microorganisms are required to produce ethanol from lignocellulosic hydrolysates using an economically feasible process. Different fermentation organisms among bacteria, yeast, and fungi (natural as well as recombinant) have been reviewed (Park et al. 2010; Talebnia et al. 2010) with emphasis on their performance over lignocellulosic hydrolysates. Types of biofuels, derived from these sources are important choices for exploiting alternative energy and reduction of environmental pollution. Lignocellulosic biomass comprising forestry, agricultural and agroindustrial wastes are abundant, renewable and inexpensive energy sources (Katzen and Echell 2006; Nwakaire, et al. 2013). Such wastes include a variety of materials such as sawdust, poplar trees, sugarcane bagasse, waste paper, brewer's spent grains, switchgrass, and straws, stems, stalks, leaves, husks, shells and peels from cereals like rice, wheat, corn, sorghum and barley, among others. Lignocellulose wastes are accumulated every year in large quantities, causing environmental problems. However, due to their chemical composition based on sugars and other compounds of interest, they could be utilized for the production of a number of value added products, 
such as ethanol, food additives, organic acids, enzymes, and others (Nwakaire et al. 2013). Therefore, besides the environmental problems caused by their accumulation in the nature, the non-use of these materials constitutes a loss of potentially valuable sources. Improvement in bioethanol research from agro waste as well as promoting sustainable alternative energy has brought about global restructuring thus sustaining growth, economy and industrialization (Rathna et al. 2014). But much is required in the area of alleviating high cost of energy sources such as wood, kerosene and gas in cooking, most especially in the rural area where risk is high.

Currently, bio-energy, besides wind and solar technology, is the most widely used among all the renewable energy technologies available domestically and internationally, taking up about two-thirds of all the renewable energy the world uses (Hernandez-Atonal et al. 2007; Wan and Lee 2010). Bio-energy refers to useable energy that is converted from biomass. Similar to wind and solar energy, bio-energy is an excellent energy recycling technology, but it has the most prospects, given its ability to turn refuse into bio-energy (Fu et al. 2005; Kupka et al. 2008). Previous studies have recycled plastic wastes from dumpsite (Chiemchaisri et al. 2010; Dalai et al. 2009) and rice straw (Huang et al. 2008; Shie et al. 2010) as refuse-derived fuel by gasification system, microwave, or plasma torch. However, some problems exists in conventional thermochemical processes, such as low gas productivity and the generation of heavy tarry compounds, causing corrosion problems for the gas collection equipment and increasing the need for the further treatment of the gas produced (Bridgwater 2003; Ferrer et al. 2005). Additionally, microwave or plasma torch technology would increase the need of electrical energy. There are important development benefits to be gained from expanding access to modern energy services. Modern energy services will help reduce poverty and play a critical role in improving educational opportunities for children, empowering women and promoting gender equality. The availability of adequate clean energy is important in reducing child mortality and further reduce exposure to pollution. It will also reduce the carrying of heavy loads of fuelwood thus improving maternal health. Finally, widespread substitution of modern energy for traditional biomass can be a rallying point for global partnerships. For many households, switching away from traditional biomass is not feasible in the short term. Improving the way biomass is supplied and used for cooking is, therefore, an important way of reducing its harmful effects. This can be achieved either through transformation of biomass into less polluting forms or through improved stoves and better ventilation. Production of ethanol cooking gel is an innovation designed through research and development towards developing a product that burns up to twice as long as other liquid fuels. Thus making the price more favourable to other liquid fuels. The production from local available raw materials makes ethanol cooking gel the most cost-effective and safe fuel available to informal housing residents and the needy. Ethanol Cooking Gel will bring water to boiling point between five to eight minutes. One litre of the Ethanol Cooking Gel will burn for a minimum of four and a half hours, almost twice as long as liquid fuels commonly used today. Ethanol Cooking Gel is odourless and smokeless when burning. Other fuels emit a strong odour when burning, which often affects the taste of the food being prepared. Ethanol Cooking Gel fuel will not change the taste of the food being prepared. Ethanol Gel Fuel is $100 \%$ organic made from bio ethanol a completely renewable energy source. The key physical and chemical properties that make up the gel ensure that it is non-toxic. This investigation was aimed at sighting research, technology and innovation into development of ethanol biogel; an alternative energy source for cooking.

\section{Sample collection}

\section{Materials And Methods}

Sawdust was collected aseptically from a sawmill located at Alimosho Local Government area in Lagos state, Nigeria, West Africa. The sample was taken to the laboratory and used as substrate for production of crude ethanol.

\section{Microorganism}

$100 \mathrm{ml}$ of Potato dextrose agar (PDA) was prepared according to manufacturer's instruction inside a $250 \mathrm{ml}$ conical flask. This was further sterilized by autoclaving at $121^{\circ} \mathrm{C}$ for 15 minutes under 15 psi pressure. A solution was prepared by weighing $1 \mathrm{~g}$ of decaying wood samples into a $9 \mathrm{ml}$ of distilled water. From the solution $1 \mathrm{ml}$ was taken and dispensed into a clean petri dish and while using pour plating method the culture medium was added. This was incubated at $300 \mathrm{o}$ for 5 days (Nardoni et al. 2005). The microbiological analysis was carried after incubation period. There was contamination observed.

\section{Ethanol production}

The sawdust fiber sample was processed mechanically to reduce the length of fibers, prior to pretreatment. After removing the minor impurities by means of washing, they were oven-dried at $60^{\circ} \mathrm{C}$ overnight. The dried fibres were grinded into powder using a ball mill grinder and subjected through the following processes for the production of ethanol which was used to achieve the final product: (i). Hot water pretreatment was employed by preparing $100 \% \mathrm{w} / \mathrm{v}$ sample, boiled at $150^{\circ} \mathrm{C}$ for $24 \mathrm{hr}$ thus removing high 
concentration of hemicellulose up to $15 \%$ and increased $55 \%$ digestibility of lignin as well as removal of microorganisms. The procedure was done twice. (ii). Enzymatic digestion was carried out by using cellulase enzyme of $2.09 \mathrm{umol} / \mathrm{min} / \mathrm{ml}$ activity having optimal conditions of $\mathrm{pH} 4.5$ and temperature of $50^{\circ} \mathrm{C}$. $1.0 \mathrm{ml}$ of the active enzyme was added to the hot water treated sawdust powder and then incubated for hydrolysis at the optimal enzymatic conditions for $24 \mathrm{hr}$ enabling digestion into glucose. (iii). Fermentation of glucose was finally carried by solid state fermentation technique using Aspergillus niger to obtain ethanol. 2\% (v/v) of overnight grown Aspergillus niger cells were then inoculated into the $100 \%$ (w/v) hydrolyzed medium which had been supplemented with $1 \%$ ammonium chloride acting as a nitrogen source. This was incubated at $30^{\circ} \mathrm{C}$ for $74 \mathrm{hr}$ in a stationary phase (Andrietta, et al. 2011).

\section{Ethanol quantification}

The analysis was focused on estimating the yield of ethanol recovered from the processing of sawdust. The ethanol content in the fermentation medium was estimated after appropriate incubation time using chromic acid method. $10 \mathrm{ml}$ of fermented medium was taken and underwent distillation process. Approximately $5 \mathrm{ml}$ of distillate was collected and combined with $25 \mathrm{ml}$ of chromic acid and content was made up to $51 \mathrm{ml}$ with sterile distilled water and kept in water bath at $80^{\circ} \mathrm{C}$ for 15 minutes, after cooling read at 600nm. (Sayyad et al. 2015; Caputi et al. 1968).

\section{Production and characterization of biogel}

The production of biogel was carried out using the following ingredients in the ratio of $70 \%$ ethanol, $10 \%$ water and $20 \%$ nitrosol (a compound made from sheep bone). This methodology was developed at the Enzyme Technology division of the biotechnology department within the Federal Institute of Industrial Research (F. I. I. R.), Lagos state, Nigeria, West Africa. The preparation was done at room temperature and analysis carried out at the Nigerian National Petroleum Cooperation, Warri, Delta state, Nigeria.

\section{Aspergillus niger}

\section{Results And Discussion}

This isolate was characterized according to (Nardoni et al. 2005) as having (i). Macroscopic Attributes: Colony diameter (around $81 \mathrm{~mm}$ ), Colony colour (black appearance), Conidia (black appearance), Mycelium (whitish appearance), No exudates, Yellow river pattern reverse, No Sclerotia. Microscopic Attributes: Conidiophore length (around $857 \mu \mathrm{m}$ ), Conidiophore breadth (about $12.3 \mu \mathrm{m}$ ), Smooth surface texture, Globular

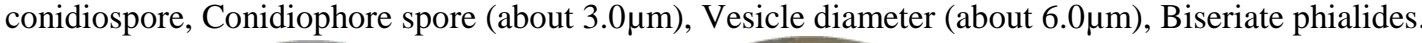

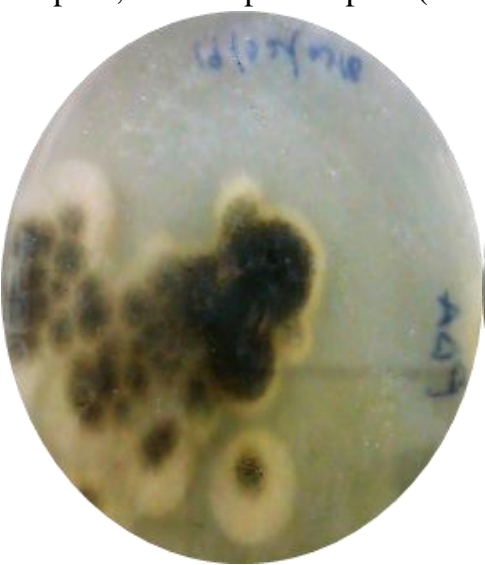

(a)

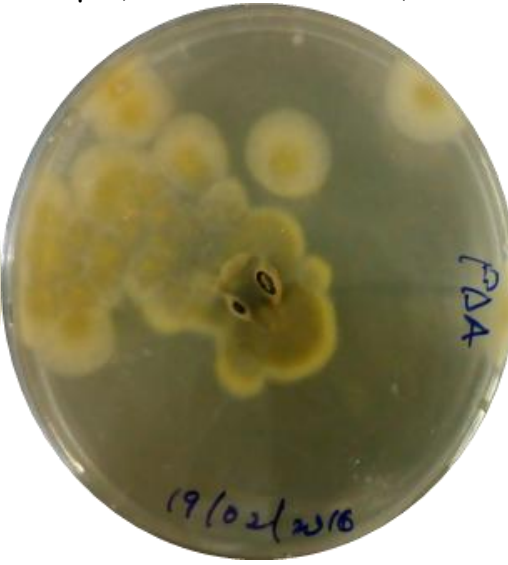

(b)

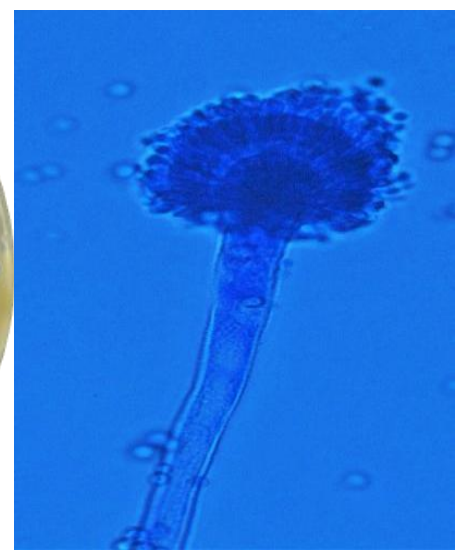

(c)

Figure 1: These are pictoral representation of Aspergillus niger after $72 \mathrm{hr}$ of growth on Potato dextrose agar (PDA) fortified with $10 \mu \mathrm{l}$ of mixed antibiotics. Figures 1 (a) is showing the surface view of the Aspergillus niger indicating the whooly whittish transformation into blackish brown towards maturity. Figure 1 (b). This figure is showing the reverse yellow river patter while Figure (c) is showing the microscopic structure of the isolate. Also presnt are young spores detaching from the parent layout. 


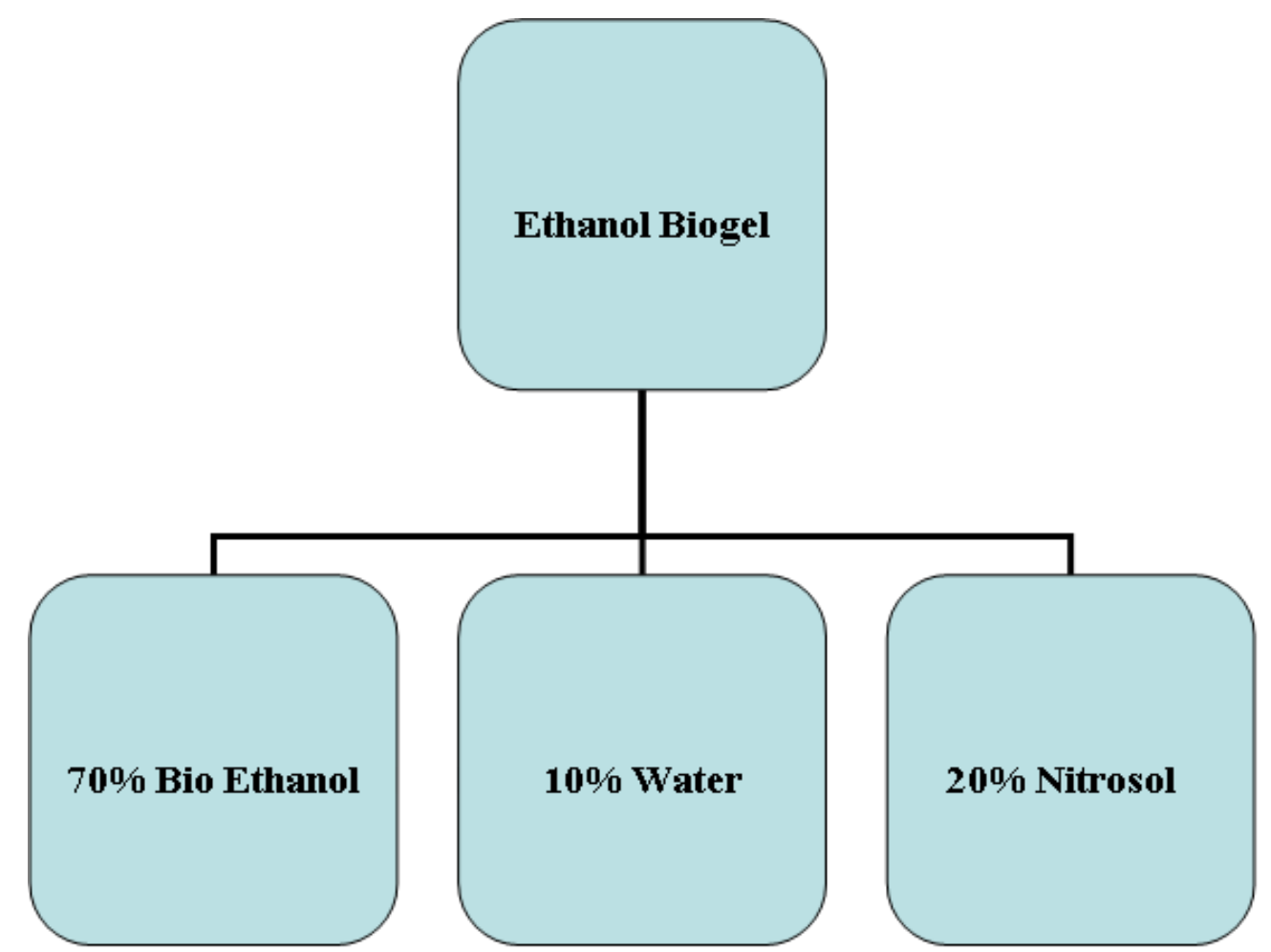

Figure 2: A flow diagram representing materials and formulation for production of ethanol biogel; an alternative source for cooking. Three ingredients as shown above were used for the production of the ethanol biogel. These are very much in abundance and thus describing the cheap production status and consistency of the product.

Table 1: Properties of ethanol bio gel recorded during analysis

\begin{tabular}{|l|l|l|}
\hline $\mathbf{S} / \mathbf{N}$ & Test & Observation \\
\hline 1. & Viscosity at $40^{\circ} \mathrm{C}$ and $80^{\circ} \mathrm{C}$ & $421.20 \mathrm{cst}$ and $210.87 \mathrm{cst}$ respectively \\
\hline 2. & Flashpoint & $26^{\circ} \mathrm{C}$ \\
\hline 3. & Density at $25^{\circ} \mathrm{C}$ & $0.908 \mathrm{~kg} / \mathrm{m} 3$ \\
\hline 4. & Total acid number & $0.12 \mathrm{mgkOH} / \mathrm{g}$ \\
\hline 5. & Pour point & $(-13 \%$ still flowing $)$, \\
\hline 6. & pH & 6.16 \\
\hline 7. & Base settlement or water content & Nil \\
\hline 8. & Colour & Bluish colour \\
\hline 9. & Combustion & Complete \\
\hline 10. & Motion & Full of motion \\
\hline 11. & Odour & Odourless \\
\hline
\end{tabular}

Table 2: Comparative analysis of cooking energy sources

\begin{tabular}{|c|c|c|c|c|}
\hline Product & Flashpoint $\left({ }^{\circ} \mathrm{C}\right)$ & Pour point $\left({ }^{\circ} \mathrm{C}\right)$ & Density (g/cm3at $\left.25^{\circ} \mathrm{C}\right)$ & Sulphur content (\% per mass) \\
\hline Biogel & 26 & 13 & 0.908 & 0.02 \\
\hline Kerosene & 51 & -47 & 0.81 & 0.04 \\
\hline Cooking Gas & -104 & -161 & 0.3 & 0.2 \\
\hline
\end{tabular}

Table 1 above is showing the properties and characteristics of the ethanol biogel product after analysis. These results indicate the safety property, environmental friendliness, nontoxic, and furthermore can easily be controlled as compared to other cooking agents described in Table $\mathbf{2}$ below. Figure 2 is showing a comparative level between ethanol biogel, kerosene and cooking gas. From the results obtained ethanol biogel is most acceptable and more environmental friendly when used. 


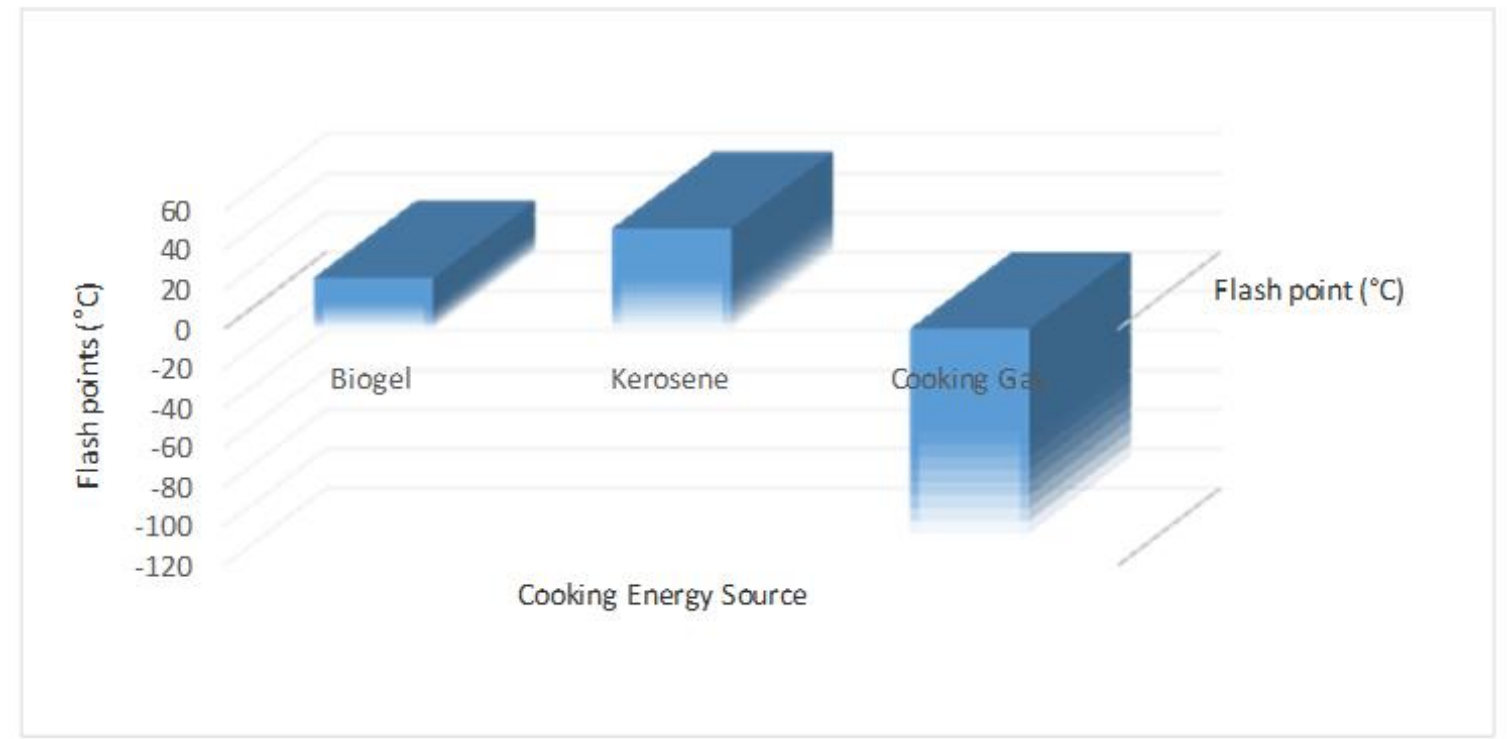

Figure 3a: Graphical representation of each cooking energy source flash point

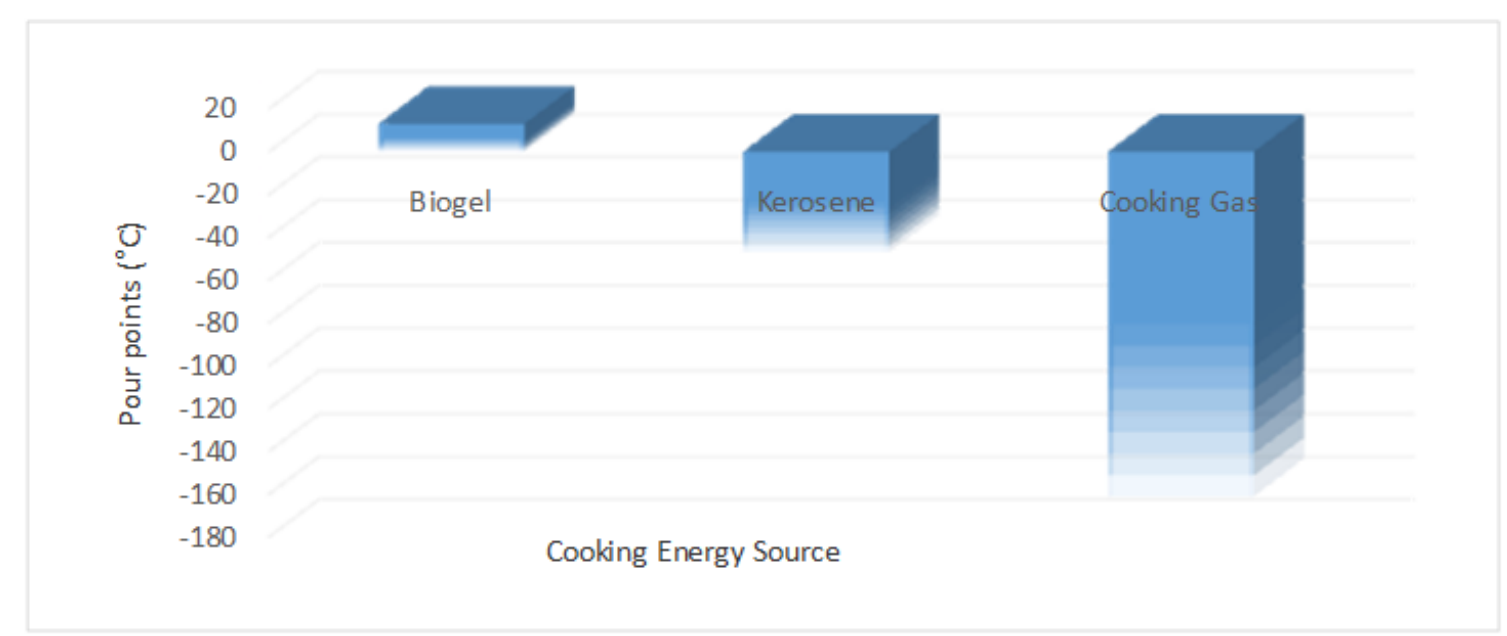

Figure 3b: Figure 2: Graphical representation of each cooking energy source pour point $\left({ }^{\circ} \mathrm{C}\right)$
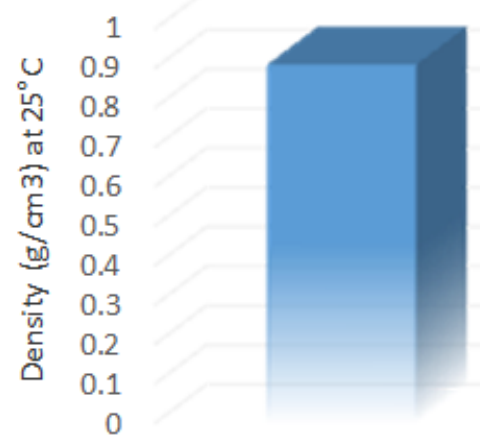

$$
\text { Biogel }
$$

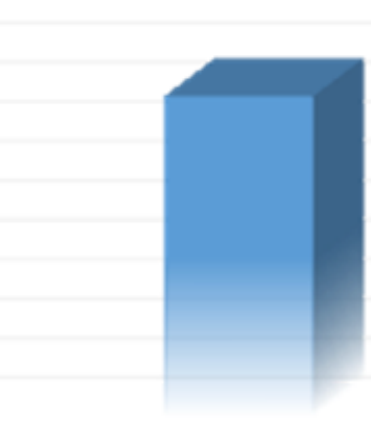

Kerosene

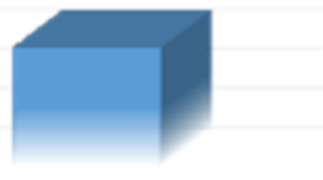

Cooking Gas

Cooking Energy Source

Figure 3c: Graphical representation of each cooking energy source density $(\mathrm{g} / \mathrm{cm} 3)$ at $25{ }^{\circ} \mathrm{C}$ 


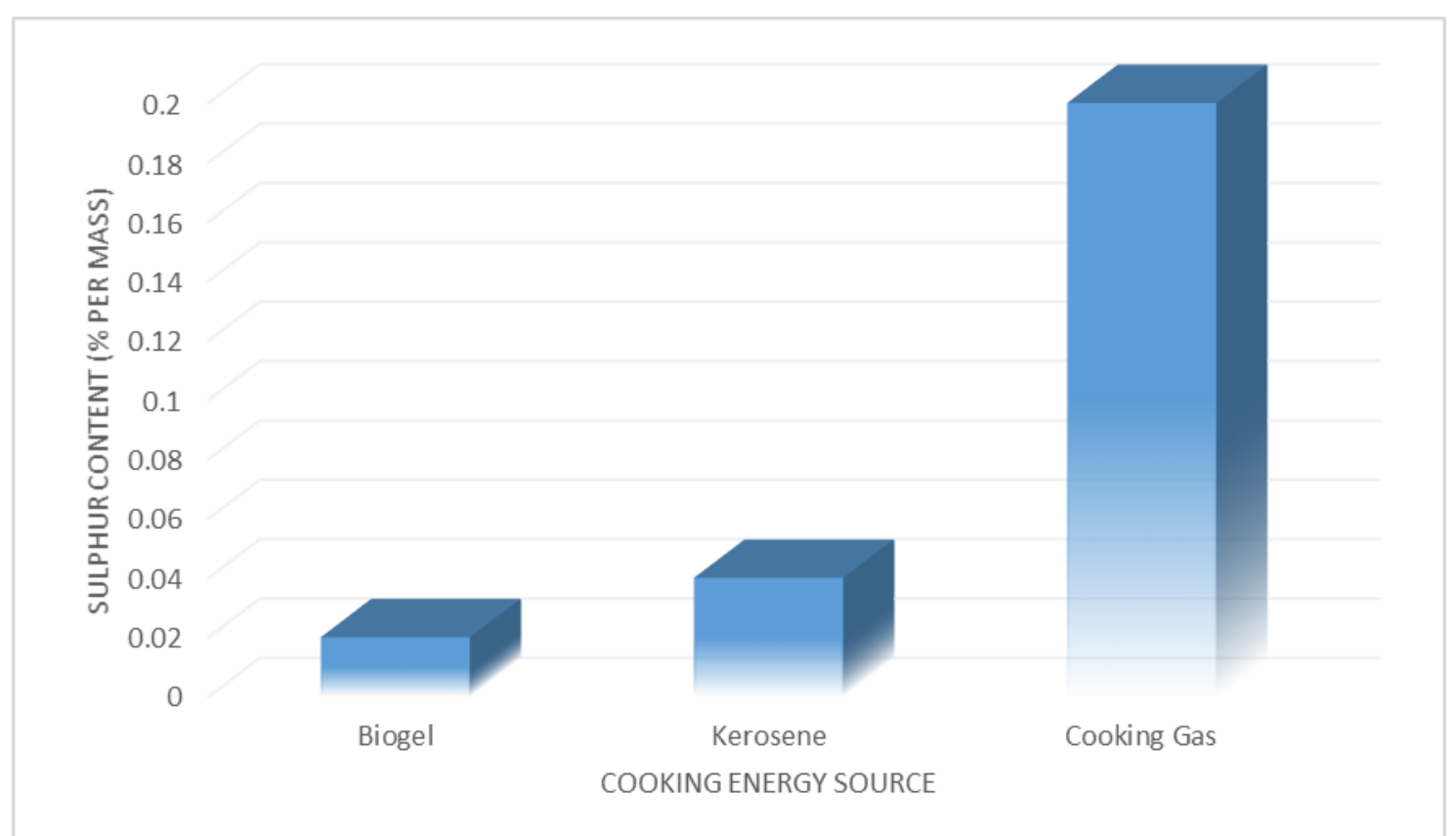

Figure 3d: Graphical representation of each cooking energy source density sulphur content (\% per mass)

The Figures 3a, 3b, 3c and 3d are graphical representation of the three cooking energy sources. Two of these are very common but studies have been proven that cost of production, purchase and usage does not make them very economical reliable and environmental friendly by end users. These graphs show the differential intensity between the products thus indicating ethanol biogel as the most acceptable amongst them. The ethanol quantification gave a measurable value of $4.8 \mathrm{~g} / 100 \mathrm{~g}$ of sample. This was recorded as there was no inducing factor and also justifying this research work as a $100 \%$ production process.

\section{Conclusion}

The innovation of ethanol biogel as an alternative energy source for cooking is based on the following: availability of raw materials, low cost of production, reduced health and environmental risk. The development of this innovative product is most relative to reducing environmental and health risk of people mostly in developing area while supporting a growing economy thus improving the lives of women and youths. The production of biogel from local raw available materials proved to be very economical, environmental friendly and thus a better alternative source of energy for cooking. Its production does not require chemical process and less mechanical process thus having reduced environmental risk. The need for conversion of waste to wealth was demonstrated in this investigation providing clean environment and healthy living thus promoting job creation, wealth creation as well as entrepreneurship. Further investigation need to be carried out in this area of research based on the following; 1). To determine the best quality of bio ethanol for an improved scale up production of byproduct and 2). Improved product development mechanism.

\section{Acknowledgment}

We wish to acknowledge Dr. Abdulkadir, I. of the Nigeria National Petroleum Cooperation, Warri, Delta state, Nigeria for providing analytical facilities to determine the properties of the product. Also a big thank you goes to Dr. Yazdani, S. S. (Head), Microbial Engineering Group, International Centre for Genetic Engineering and Biotechnology for advisory support towards this research

\section{References}

[1]. Andrietta, M. G. S., Andrietta, S. R. and Stupiello, E. N. A. 2011. Bioethanol what has Brazil learned about yeasts inhabiting the ethanol production processes from sugar cane? In: Bernardes, M.A.S. (ed.). Biofuel production -recent developments and prospects. InTech, Rijeka, 67-84.

[2]. Bridgwater, A.V. 2003. Renewable fuels and chemicals by thermal processing of biomass. Chemical Engineering Journal 91: 87102.

[3]. Caputi, A. J. and Ueda M. B. T. 1968. Spectrophotometric determination of ethanol in wine. Am. J. Enol. Vitic., 19:160-165

[4]. Chiemchaisri, C., Charnnok, B. and Visvanathan, C. 2010. Recovery of plastic wastes from dumpsite as refuse-derived fuel and its utilization in small gasification system. Bioresource Technology 101:1522-1527. 
[5]. Dalai, A.K., Batta, N., Eswaramoorthi, I. and Schoenau, G. J. 2009. Gasification of refuse derived fuel in a fixed bed reactor for syngas production. Waste Management 29:252-258.

[6]. Ferrer, E., Aho, M., Silvennoinen, J. and Nurminen, R.V. 2005. Fluidized bed combustion of refuse-derived fuel in presence of protective coal ash. Fuel Processing Technology 87(1):33-44.

[7]. Fu, Z. M., Li, X. R. and Koseki, H. 2005. Heat generation of refuse derived fuel with water. Journal of Loss Prevention in the Process Industries 18(1):27-33.

[8]. Hernandez-Atonal, F. D., Ryu, C., Sharifi, V. N. and Swithenbank, J. 2007. Combustion of refuse-derived fuel in a fluidised bed. Chemical Engineering Science 62(1-2):627-635.

[9]. Huang, Y. F., Kuan, W. H., Lo, S. L. and Lin, C. F. 2008. Total recovery of resources and energy from rice straw using microwaveinduced pyrolysis. Bioresource Technology 99:8252-8258.

[10]. International Energy Agency 2014. World Energy Outlook, 2014.

[11]. Katzen, R, and Echell, K. 2006. Lignocellulosic Feedstock Bioretinery. Pig., 1:129-138

[12]. Kupka, T., Mancini, M., Irmer, M. and Weber, R. 2008. Investigation of ash deposit formation during co-firing of coal with sewage sludge, saw-dust and refuse derived fuel. Fuel 87(12), 2824-2837.

[13]. Mcaloon, A. Taylor, F., Yee, W., Ibsen, K. and Wooley R. 2000. Determining the cost of producing ethanol from corn starch and lignocellulosic feedstocks. Report No. NREL/TP-580-28893. Eastern Regional Research Centre, Wyndmoor P.A., and National Renewable Energy Laboratory, Golden Co.

[14]. Nardoni, S., Mancianti, F., Sgorbini, M. and Taccini, F. 2005. Identification and seasonal distribution of airborne fungi in three horse stables. J Mycopathologia 160:29-34.

[15]. Nwakaire, J.N., S.L., Ezeoha and Ugwuishiwu B.O. 2013. Production of cellulosic ethanol from wood sawdust, Agric. Eng. Int.: CIGR Journal, 15(3):136-140.

[16]. Park, I., Kim, I., Kang, K., Sohn, H., Rhee, I., Jin, I. and Jang, H. 2010. Cellulose ethanol production waste newsprint by simultaneous sacchariffication and fermentation. Process Biochem., 45(4): 487

[17]. Rathna, G. S., Saranya, R. and Kalaiselvam, M. 2014. Bioethanol from sawdust using cellulase hydrolysis of Aspergillus ochraceus and fermentation by Saccharomyces cerevisiae Int.J.Curr.Microbiol.App.Sci 3(12): 733-742.

[18]. Sander, K., Hyseni, B. and Haider, S. W. 2011. Wood-Based Biomass Energy Development for Sub-Saharan Africa: Issues and Approaches. Working Paper No. 74545. The World Bank, Washington, DC

[19]. Sayyad, S. F., Chaudhari, S. R. and Panda, B. P. 2015. Quantitative determination of ethanol in arishta by using UVvisible spectrophotometer. Pharmaceutical and Biological Evaluations; 2 (5): 204-207.

[20]. Shie, J. L., Tsou, F. J., Lin, K. L. and Chang, C.Y. 2010. Bioenergy and products from thermal pyrolysis of rice straw using plasma torch. Bioresource Technology 101:761-768

[21]. Talebnia, F., Karakashv, D. and Angelidaki, I. 2010. Production of bioethanol from wheat straw: An overview on pretreatment, hydrolysis and fermentation. Bioresource Technology, 101(13): 4744- 4753.

[22]. Wan, H. P. and Lee, H. T. 2010. The use of refuse-derived fuel. Scientific Development 450:34-43.

[23]. Yasuyuki, M., Toyoki, I., Yasuo, T. T. H. and Kazuhiko F. (2011). Conversion of sulfuric acid lignin generated during bioethanol production from lignocellulosic materials into polyesters with ecaprolactone. J. Wood Sci., 57: 214-218. 